\title{
Would Forest Litter Cause a Risk of Increased Copper Solubility and Toxicity in Polluted Soils Remediated via Phytostabilization?
}

\author{
Mateusz Cuske ${ }^{1 *}$, Anna Karczewska ${ }^{1}$, Bernard Gałka ${ }^{1}$, \\ Konrad Matyja ${ }^{2,3}$
}

${ }^{1}$ Institute of Soil Science and Environmental Protection, Wrocław University of Environmental and Life Sciences, Grunwaldzka 53, 50-375Wrocław, Poland

${ }^{2}$ Wrocław University of Technology, Environmental Engineering Faculty, Wyb.Wyspiańskiego 27, 50-370 Wrocław, Poland

${ }^{3}$ Wrocław University of Technology, Faculty of Chemistry Group of Bioprocess and Biomedical Engineering Norwida 4/6, 50-373 Wrocław

Received: 30 August 2016

Accepted: 14 September 2016

\begin{abstract}
Soil solutions were collected from soils contaminated differently by the emissions from a copper smelter and incubated with beech litter. Five times in 30 days of incubation, soil solutions were acquired with MacroRhizon samplers and examined using the chemometric approach and two ecotoxicological assays: Microtox with Vibrio fischeri bacteria and Phytotoxkit with Sinapis alba seeds. Copper speciation in soil solutions was modeled in the MinteQ program. Application of beech litter to soils resulted in a considerable increase of copper solubility. The toxicity of soil solutions was associated with total copper concentrations in solutions, copper speciation, and $\mathrm{pH}$ values. The toxicity measured by the Phytotoxkit test in soil solutions collected from non-amended soils was higher than that measured in Microtox, and was attributed to high concentrations of copper organic complexes in solutions. The application of beech litter, rich in dissolved organic carbon DOC, resulted in a radical increase of soil solution toxicity to both indicating organisms. This effect, particularly well expressed in the case of $V$. fischeri, was apparently caused by a decrease in $\mathrm{pH}$ and associated increase of total $\mathrm{Cu}$ concentrations in solutions.
\end{abstract}

Keywords: copper organic complexes, DOC, forest litter, Microtox, Phytotoxkit

*e-mail: mateusz.cuske@gmail.com 


\section{Introduction}

The most common method used for remediation of soils polluted with heavy metals, such as those surrounding a copper smelter, is immobilization of metals followed by land afforestation. Such a treatment may, however, create hazards associated with an increase of copper solubility in afforested areas caused by the influence of organic matter that derives from forest litter. Copper has a high affinity to organic matter [1-3] and can be complexed by low molecular weight organic acids produced from decomposing litter [4-6]. Moreover, microbiological decomposition of litter leads to acidification of the soil environment, which may directly contribute to enhanced desorption of copper into soil solution. Typically, the higher the concentration of copper in soil solution, the greater its toxicity to soil fauna and flora [7]. However, copper speciation also plays an important role in determining the toxicity of soil solutions. Therefore, simple chemical analyses may be insufficient for the assessment of environmental risk. A more advanced characteristic of contamination that involves speciation studies and recognition of toxicity associated with different forms of pollutants will be necessary for monitoring contaminated areas [8-11].

Several studies carried out in afforested areas contaminated with heavy metals proved that there is a risk of mobilization of copper and other metals from soils by organic acids derived from forest litter [12-13]. It is still unclear, however, if the mobile forms of heavy metals released into soil solutions derived mainly from a mineral matrix of contaminated soils or from metal-enriched forest litter itself.

The aim of this study was to determine the influence of forest litter that may be formed in afforested copperpolluted soils, on possible release of copper from soil solid phase, and to examine the time changes of concentrations, speciation, and toxicity of copper present in soil solutions.

\section{Experimental}

Five soils differently contaminated with heavy metals, mainly with copper, were collected from the close vicinity of the copper smelter Legnica - an area that was previously remediated by liming and phytostabilized by afforestation. Soil material was air dried, sieved, homogenized, and mixed with a beech litter (BL) obtained from an uncontaminated area. Basic properties of soils and litter were determined using the methods described by Tan [14] and reported in more detail elsewhere [15].

An incubation experiment was conducted over 30 days. Soil material (control soils) and soil material mixed with beech litter (50 g per $1 \mathrm{~kg}$ ) were supplied with distilled water and incubated at moisture ca. $80 \%$ of field capacity. Soil solutions were obtained repeatedly in 1, 2, 7, 14, and 30 days of incubation using MacroRhizon samplers. The concentrations of copper and other major components of soil solutions, including dissolved organic carbon DOC as well as $\mathrm{pH}$, were determined by the methods described by Cuske et al. [15]. The toxicity of soil solutions was measured using two tests: a Microtox assay based on inhibition of Vibrio fischeri bioluminescence, and a Phytotoxkit assay based on inhibition of seed germination and root and shoot elongation, carried out with Sinapis alba. More detailed information on experimental methodology was provided elsewhere [15].

$\mathrm{Cu}$ speciation in soil solution was determined by MinteQ v. 3.1 program. The SHM (Stockholm Humic Model) model was adopted for modeling the organic components of DOC in soil solutions.

\section{Results and Discussions}

Analyzed soils differed significantly in total content of heavy metals (especially copper) and the concentrations of dissolved organic carbon. In addition, their $\mathrm{pH}$ values differed considerably (Table 1). The beech litter contained $3.7 \mathrm{~g} \mathrm{~kg}^{-1}$ of dissolved organic carbon (DOC), and indicated acidic reaction. The concentrations of heavy metals in the litter were negligible (Table 1).

Copper concentrations in soil solutions obtained from non-amended polluted soils, examined in previous studies, turned out to depend primarily on soil $\mathrm{pH}$ values, and then on total concentrations of $\mathrm{Cu}$ in soils [16-17]. The differences in DOC concentrations in nonamended soils were small, and therefore this factor had no significant impact on diversity of $\mathrm{Cu}$ concentrations in soil solutions of untreated soils (Figs 1-3) [17]. However, the concentrations of $\mathrm{Cu}$ in soil solutions of BL-amended soils were considerably higher in comparison to soil solutions of control soils (Figs 1-3). This effect may be explained by two mechanisms. First, a decrease in the $\mathrm{pH}$ values of soils after the application of acidic forest litter resulted in an intensive desorption of copper into soil solution $[9,18]$. Secondly, released copper was bound by low molecular weight organic acids (formed as a result of litter decomposition in biochemical processes) and transformed into the complexed forms [4, 6, 19]. The highest

Table 1. Basic chemical properties of soils and forest litter applied

\begin{tabular}{|c|c|c|c|c|c|}
\hline \multicolumn{2}{|c|}{ Material } & $\mathrm{C}_{\text {org. }}$ & $\mathrm{DOC}$ & $\mathrm{pH}$ & $\mathrm{Cu}_{\text {tot. }}$ \\
\cline { 2 - 6 } & $\%$ & $\mathrm{~g} \mathrm{~kg}^{-1}$ & $\begin{array}{c}\text { in } 1 \mathrm{M} \\
\mathrm{KCl}\end{array}$ & $\mathrm{mg} \mathrm{kg}^{-1}$ \\
\hline \multirow{4}{*}{ Soils } & 1 & 0.90 & 0.85 & 7.38 & 5180 \\
\cline { 2 - 6 } & 2 & 0.76 & 0.80 & 6.41 & 3732 \\
\cline { 2 - 6 } & 3 & 1.30 & 1.80 & 5.22 & 1686 \\
\cline { 2 - 6 } & 4 & 0.66 & 1.40 & 7.00 & 531 \\
\cline { 2 - 6 } & 5 & 0.93 & 1.60 & 7.15 & 301 \\
\hline $\begin{array}{c}\text { Beech } \\
\text { litter }\end{array}$ & $\mathrm{BL}$ & 34.6 & 3.7 & 5.5 & 25 \\
\hline
\end{tabular}


concentrations of copper $\left(15.4 \mathrm{mg} \mathrm{L}^{-1}\right)$ were found in soil solutions collected from soil No. 2 supplied with beech litter (Fig. 2) in the firsts days of incubation. The lowest concentrations of $\mathrm{Cu}\left(0.11-0.17 \mathrm{mg} \mathrm{L}^{-1}\right)$ were observed in

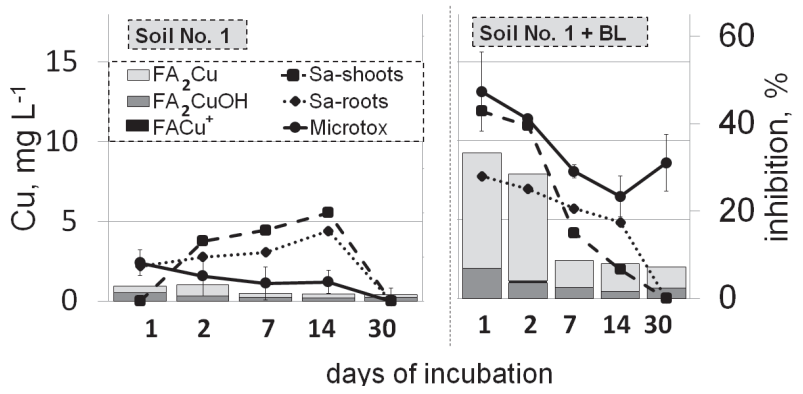

Fig. 1. Concentrations of $\mathrm{Cu}$ species and toxicity indices of soil solutions extracted from soil No. 1 - nonamended (left) and treated with a beech litter (right). Luminescence inhibition of $V$. fischeri in Microtox assay (Microtox) and inhibition of elongation measured in Phytotoxkit for shoots (Sa-shoots) and roots (Sa-roots) of Sinapis alba (right axis) are shown as related to the concentrations $\left(\mathrm{mg} \mathrm{L}^{-1}\right)$ of predominant $\mathrm{Cu}$ species in soil solutions (left axis). FA (abbreviation of "fulvic acids") stands for organic ligands in soluble $\mathrm{Cu}$ complexes (as modeled in MinteQ). Error bars indicated for Microtox data represent a standard deviation.

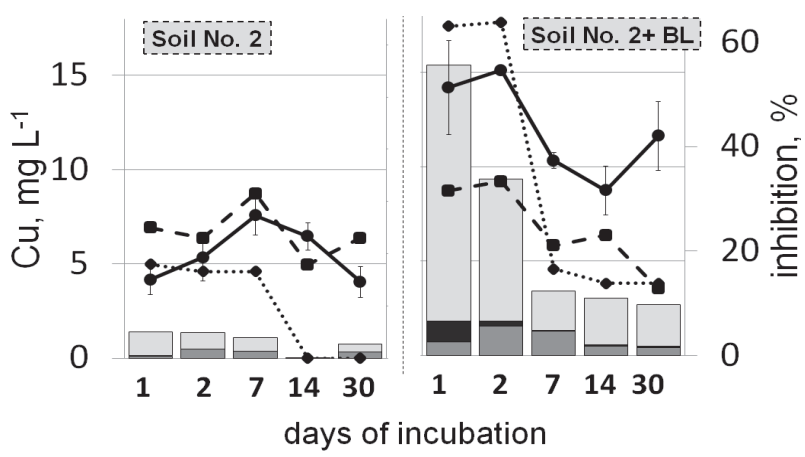

Fig. 2. Concentrations of $\mathrm{Cu}$ species and toxicity indices of soil solutions extracted from soil No. 2 - nonamended (left) and treated with a beech litter (right; see Fig. 1 for explanations).

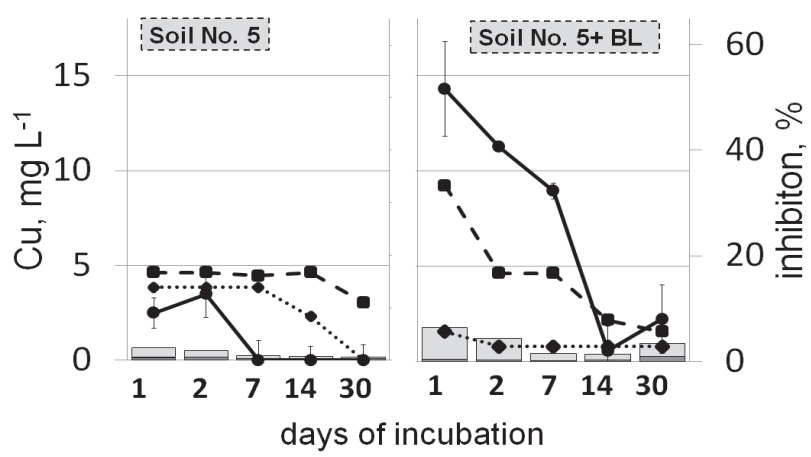

Fig. 3. Concentrations of $\mathrm{Cu}$ species and toxicity indices of soil solutions extracted from soil No. 5 - nonamended (left) and treated with a beech litter (right; see Fig. 1 for explanations). soil solutions obtained from the least polluted, untreated soil Nos. 4-5 (Fig. 3) in the lasts days of incubation.

Almost $100 \%$ of copper present in soil solutions occurred in the forms complexed with low molecular organic matter, specified as $\mathrm{FA}_{2} \mathrm{Cu}, \mathrm{FA}_{2} \mathrm{CuOH}$, and $\mathrm{FACu}^{+}$, where the symbol FA stands for various soluble organic compounds, and represented in the SHM model by fulvic acids, which is confirmed by other studies [20]. The presence of free copper ions $\mathrm{Cu}^{2+}$ in soil solutions, in trace concentrations, was only confirmed in the case of soil Nos. 2 (Fig. 2) and 3, in the first and last days of incubation, when the $\mathrm{pH}$ values were, due to $\mathrm{BL}$ application, the lowest. In those cases, the cationic forms of free $\mathrm{Cu}^{2+}$ made up ca. $0.03 \%$ of soluble copper.

The concentrations of particular forms of copper complexed organically $\left(\mathrm{FA}_{2} \mathrm{Cu}, \mathrm{FA}_{2} \mathrm{CuOH}\right.$, and $\mathrm{FACu}^{+}$) in the solutions of control soils were dependent mainly on soil $\mathrm{pH}$ values. The predominating forms of copper complexes in soil solutions were non-ionic complexes $\mathrm{FA}_{2} \mathrm{Cu}$, the contribution of which ranged from 59.3 to 93.6\% (Figs 1-3). The highest concentrations of these complexes were observed in soil solutions collected from soil Nos. 2-3 (with the lowest $\mathrm{pH}$ values; Fig. 2). In those solutions, the contributions of ionic $\mathrm{FACu}^{+}$complexes were higher compared to soil solutions collected from the other soils. In turn, the soil solutions of more alkaline soils (Nos 1, 4-5) contained higher contributions of nonionic hydroxyl-copper complexes $\mathrm{FA}_{2} \mathrm{CuOH}$ (Fig. 1). Applying beech litter to soils did not significantly affect the main patterns of copper speciation in soil solutions. However, the contributions of hydroxyl-copper complexes $\mathrm{FA}_{2} \mathrm{CuOH}$ were in the case of BL-treated soils Nos. 1 (Fig. 1), 3, and 4 - significantly higher than in control soils. Additionally, in soil solutions of BL-treated soils, Nos. 2-3 (i.e., those with the lowest $\mathrm{pH}$ values; Fig. 2), the contributions of ionic copper complexes $\mathrm{FACu}^{+}$increased significantly compared to non-treated soils.

Total concentrations of copper in soil solutions collected from untreated soils, as well as from all BLtreated soils, tended generally to decrease with time, which may be explained by a so-called "aging effect" associated with stabilization of contaminants bound to transformed, stable organic matter [21]. In some cases in our experiment, i.e., in soil solutions of control soil No. 2 and BL-treated soil No. 5, an apparent, though statistically insignificant, increase of copper concentrations was observed after 30 days of incubation. Similar observations were also reported by several other authors, but the mechanisms involved in such an effect remain unclear and need further investigation [22-23].

The toxicity of soil solutions differed greatly in the experiment, depending on $\mathrm{pH}$ values of soil solutions, the time of incubation, and total concentrations of heavy metals (particularly of copper) in soils (Figs 1-3). The results obtained from two different ecotoxicological tests were different, depending clearly on the type of testing organism.

Soil solutions of untreated soil Nos 4-5 indicated the lowest toxicity, with the inhibition of $V$. fischeri 
luminescence oscillating at the level of $10 \%$, and the maximum inhibition of Sinapis alba roots and shoots elongation at $14 \%$ and $17 \%$, respectively. Relatively low total concentrations of copper in these two soils, as well as their considerably high $\mathrm{pH}$ values, explained low concentrations of copper released into soil solutions [24] and their low toxicity. In fact, all soil solutions obtained from non-treated soils indicated toxicity below $20 \%$, and according to a toxicity and hazard system for natural waters elaborated by Persoone et al. [25], would be classified as class I: "no acute hazard".

The toxicity of soil solutions acquired from BL-treated soils, measuerd in both Microtox and Phytotoxkit assays, was definitely higher compared to the solutions of control, non-treated soils. Generally, a Phytotoxkit assay indicated higher sensitivity than Microtox in the case of soil solutions collected from control soils. On the contrary, soil solutions of BL-treated soils exhibited higher toxicity if measured in Microtox test compared to Phytotoxkit assay. It was undoubtedly associated with lower $\mathrm{pH}$ values of soil solutions (after the application of beech litter), to which $V$. fisherii bacteria are particularly sensitive [26]. Numerous studies have confirmed that the microorganisms used in the Mixrotox test are highly sensitive to the changes of $\mathrm{pH}$ and the presence of ionic forms of copper in solution [27-28]. In contrast, copper species complexed with low molecular organic matter are particularly intensively taken up by plants [15], which results in high sensitivity of Phytotoxkit assay to enhanced concentrations of organically complexed $\mathrm{Cu}$ in solution.

Applying soil solutions into incubation plates containing the seeds of Sinapis alba generally caused a higher inhibition of root elongation compared to the elongation of shoots. This observation stays in agreement with other studies that proved the particularly high accumulation of contaminants in early stages of plant growth in plant roots and a substantial reduction of root elongation compared to the shoots [29-30]. However, the results obtained in the case of soil solutions acquired in the first two days from BL-treated soil No. 2 were opposite; and the inhibition of shoot elongation was stronger compared to roots. It should be stressed that the toxicity of those solutions (BL-treated, No.2), measured in both tests, was the highest of all the solutions examined, and related $\mathrm{pH}$ values were the lowest ( $\mathrm{pH}$ 6.5-7.1).

The toxicity of soil solutions, both of control soils and BL-treated soils, decreased with time. After the seventh day of incubation, a substantial decrease in the toxicity was observed in all treatments and was proved by all the tests. Such an effect was apparently associated with decreasing concentrations of copper in soil solutions and a slight increase of $\mathrm{pH}$ values. Exceptionally, a statistically insignificant increase of toxicity was noted in the case of soil solutions collected from some BL-treated soils in the lasts days of incubation. This effect was particularly well seen in the Microtox assay results, and should probably be attributed to the slight decrease in $\mathrm{pH}$ values over time.

Our previous studies, carried out with the same soils [15-17] showed that the concentrations of lead and zinc, i.e., two other potentially toxic metals, in the soil solutions of control soils were low (in the ranges $0.01-0.09 \mathrm{mg} \mathrm{L}^{-1}$ and $0.03-1.50 \mathrm{mg} \mathrm{L}^{-1}$, respectively), and had no effect on the toxicity measured in both tests. This statement was confirmed by the results of a PCA analysis presented elsewhere [15].

\section{Conclusions}

The formation of forest litter and its decomposition in soils contaminated with heavy metals, in particular with copper, may be a cause of increasing solubility of metals, both in effect of their complexing by low-molecularweight organic matter and due to a decrease of soil and soil solution $\mathrm{pH}$ values generated by microbiological decomposition of the litter.

Regardless of soil $\mathrm{pH}$, the presence of decomposing forest litter may cause a release of copper from heavily contaminated soils into soil solution, which in turn will result in increased toxicity of soil solutions. This observation confirms the need for further research, including field studies, to examine the real environmental risk associated with the release of heavy metals from polluted soils due to their complexing with organic compounds derived from forest litter.

The highest toxicity of soil solutions, measured in the biotests with Vibrio fischeri and Sinapis alba, was observed in the first two days of incubation. Then, both the concentrations of $\mathrm{Cu}$ in soil solutions and their toxicity tended to decrease considerably with time. However, in the case of soils with relatively low $\mathrm{pH}$ values, a secondary slight increase of copper concentrations and the toxicity of solutions was observed after 30 days of incubation. Therefore, further studies on long-term changes of copper concentrations in soil solutions and their toxicity should be carried out with forest-litter-affected, highly contaminated soils.

\section{References}

1. KARCZEWSKA A. Metal species distribution in top- and sub-soil in an area affected by copper smelter emissions. Appl. Geochem. 11 (1-2), 35, 1996.

2. KARCZEWSKA A., ORLOW K., KABALA C., SZOPKA K., GALKA B. Effects of chelating compounds on mobilization and phytoextraction of copper and lead in contaminated soils. Commun. Soil. Sci. Plant. Anal. 42, 1379, 2011.

3. RUTKOWSKA B., SZULC W. Speciation of $\mathrm{Cu}$ and $\mathrm{Zn}$ in soil solution in a long-term fertilization experiment. Soil. Sci. Ann. 65 (1), 25, 2014.

4. HONGVE D., VAN HEES, P.A.W., LUNDSTRÖM, U.S. Dissolved components in precipitation water percolated through forest litter. Eur. J. Soil. Sci., 51 (4), 667, 2000.

5. KARCZEWSKA A., GAŁKA B., GERSZTYN L., POPIELAS K. Effects of forest litter on copper and zinc solubility in polluted soils - examined in a pot experiment. Fresen. Environ. Bull. 22 (4), 9492013.

6. SMAL H., MISZTAL M. Soil solution chemistry in the 
profiles of forest and arable light textured soils, SE Poland. Appl. Geochem. 11 (1), 81, 1996.

7. WYSZKOWSKA J., KUCHARSKI J., LAJSZNER W. Enzymatic activities in different soils contaminated with copper. Pol. J. Environ. Stud. 14 (5), 659, 2005.

8. BRAND L.E., SUNDA W.G., GUILLARD R.R.L. Reduction of marine phytoplankton reproduction rates by copper and cadmium. J. Exp. Mar. Biol. Ecol. 96 225, 1986.

9. NOLAN A.L., LOMBI E., MCLAUGHLIN M.J. Metal bioaccumulation and toxicity in soils - why bother with speciation? Aust. J. Chem. 56 (3), 77, 2003.

10. SUNDA W.G., GUILLARD R.R.L. The relationship between cupric ion activity and the toxicity of copper to phytoplankton. J. Mar. Res. 34, 511, 1976.

11. SUNDA W.G.HUNTSMAN S.A. The use of chemiluminescence and ligand competition with EDTA to measure copper concentration and speciation in seawater. Mar. Chem. 36, 137, 1991.

12. KABAŁA C., KARCZEWSKA A., MEDYŃSKAJURASZEK A. Variability and relationships between $\mathrm{Pb}$, $\mathrm{Cu}$, and $\mathrm{Zn}$ concentrations in soil solutions and forest floor leachates at heavily polluted sites. J. Plant. Nutr. Soil. Sc. 177 (4), 573, 2014.

13. MEDYŃSKA A., KABAŁA C. Heavy metals concentration and extractability in forest litters in the area impacted by copper smelter near Legnica. Ecol. Chem. Eng. 17 (8), 981, 2010.

14. TAN K.H. Soil sampling, preparation, and analysis. 2nd ed. Boca Raton (FL): CRC Press. 2005.

15. CUSKE M., KARCZEWSKAA., GAŁKA B., DRADRACH A. Some adverse effects of soil amendment with organic materials - the case of soils polluted by copper industry phytostabilized with red fescue. Int. J. Phytorem. 18 (8), 846, 2016

16. CUSKE M., KARCZEWSKA A., MATYJA K., GAŁKA B. Ecotoxicity and phytotoxicity of soil solutions extracted from $\mathrm{Cu}$-contaminated soils amended with organic waste materials. Fresen. Environ. Bull. (Accepted in press) 2017.

17. CUSKE M., KARCZEWSKA A., GAŁKA B. Copper and other metals in soil solutions of strongly polluted soils treated with organic wastes. Pol. J. Environ. Stud. (Accepted in press) 2017.

18. KABATA-PENDIAS A. Trace elements in soils and plants. CRC press 2010.
19. GAMBLE D.S., SCHNITZER M., HOFFMAN I. $\mathrm{Cu}^{2+}$ fulvic acid chelation equilibrium in $0.1 \mathrm{M} \mathrm{KCl}$ at $25.0^{\circ} \mathrm{C}$. Can. J Chemistry. 48 (20), 3197, 1970.

20. MOCEK A., SPYCHALSKI W., COBEK A., MOCEKPŁÓCINIAK A. Comparison of three methods of copper speciation in chemically contaminated soils. Pol. J. Environ. Stud. 21 (1), 159, 2012.

21. SMOLDERS E., OORTS K., VAN SPRANG P., SCHOETERS I., JANSSEN C.R., MCGRATH S.P., MCLAUGHLIN M.J. Toxicity of trace metals in soil as affected by soil type and aging after contamination: using 295 calibrated bioavailability models to set ecological soil standards. Environ. Toxicol. Chem. 28 (8), 1633, 2009.

22. WANG G., STAUNTON S. Evolution of water-extractable copper in soil with time as a function of organic matter amendments and aeration. Eur. J. Soil Sci. 57 (3), 372, 2006.

23. CUI Y.S., DU X., WENG L.P., ZHU Y.G. Effects of rice straw on the speciation of cadmium $(\mathrm{Cd})$ and copper $(\mathrm{Cu})$ in soils. Geoderma, 146 (1), 370, 2008.

24. CUSKE M., GERSZTYN L., KARCZEWSKA A. The influence of $\mathrm{pH}$ on solubility of copper in soils contaminated by copper industry in Legnica. Civil and Environmental Engeneering Reports 11, 31, 2013.

25. PERSOONE G., MARSALEK B., BLINOVA I., TÖRÖKNE A., ZARINA D., MANUSADZIANAS L., NALECZJAWECKI G., TOFAN L., STEPANOVA N., TOTHOVA L., KOLAR B. A practical and user-friendly toxicity classification system with microbiotests for natural waters and wastewaters. Environ. Toxicol. 18 (6), 395, 2003.

26. VASSEUR P., BOIS F., FERARD J.F., RAST C. Influence of physicochemical parameters on the Microtox test response. Toxic. Assess. 1 (3), 283, 1986.

27. GADD G.M., GRIFFITHS A.J. Microorganisms and heavy metal toxicity. Microb. Ecol. 4 (4), 303, 1977.

28. GILLER K.E., WITTER E., MCGRATH S.P. Heavy metals and soil microbes. Soil Biology and Biochemistry. 41 (10), 2031, 2009.

29. MOLNÁROVÁ M., FARGAŠOVÁA. Relationship between various physiological and biochemical parameters activated by cadmium in Sinapis alba L. and Hordeum vulgare L. Ecol. Eng. 49, 65, 2012.

30. MOLNÁROVÁ M., FARGAŠOVÁ A. Se (IV), Se (VI), Cu and $\mathrm{Zn}$ phytotoxicity in correlation to their accumulation in Sinapis alba L. seedlings. Accepted. 2016. 
